\title{
Comparison of Results obtained by Different Methods of Individual Dietary Survey
}

\author{
By E. R. BRANSBY, Ministry of Health, Whitehall; London, S.W. I \\ AND C. G. DAUBNEY AND J. KING \\ Department of the Government Chemist, Strand, London, W.C. 2
}

(Received 6 December 1947)

The purpose of the investigation was to compare the results obtained by four methods of individual dietary survey: weighing, questioning, homely measures and chemical analysis. The work fell into two parts: a study in the National Children's Home, Harpenden, of the four methods under review, and a study of the diets of schoolchildren in Ealing by weighing and questioning. One of us (E.R.B.) was responsible for the field work of the inquiry, while two of us (C.G.D., J.K.) were responsible for the chemical analyses of the diets collected in the National Children's Home, Harpenden. The four methods of survey which were compared are described below.

Weighing. In the precise weighing method, developed by McCance \& Widdowson, the foods eaten are weighed in the home at meal times. The method has, for example, been used by them to study the diets of adult women, expectant mothers and children (Widdowson, 1936; Widdowson \& McCance, 1936; Widdowson, 1947), and by Fowke (1945) to study adolescents.

Questioning. In this method, developed by Wiehl (1942), informants are questioned on the amount of food eaten in some previous period, which is usually $24 \mathrm{hr}$. although Wiehl has obtained 2 day dietary histories at a single interview. There have been several subsequent variations and developments of the method, but, broadly, the person making the survey is supplied with foods, such as loaves and slices of bread, cooked potatoes and milk, or with models or photographs of foods, with spoons and cups of different capacities, and scales. The informant is interviewed in some convenient place, such as school or factory, and indicates the amounts of the several foods eaten during the period under examination. An interview takes about $10 \mathrm{~min}$. Wiehl (1942, 1944) has used the method to study the diets of children aged II-17 years and of men up to 60 years working in a factory; Chattaway, Happold \& Happold (1946) to examine the diets of children aged 8-14 years; and Pyke (1945) to obtain data on the foods eaten by male and female industrial workers.

Homely measures. The amounts of food eaten by the persons being studied are recorded in ordinary domestic units, such as cupfuls, spoonfuls, or sizes, weights and measures. Cups and spoons of a uniform size are sometimes provided, together with photographs or models of foods, with which the actual amounts eaten are compared. Youmans, Patton \& Keon (1942) have used the method to study the diets of individuals 
of various ages, and Bransby \& Wagner (1945) to study the diets of children. The information is recorded by the housewife in the home at meal times, not by the child whose diet is being studied.

Chemical analysis. Duplicate portions are taken of the foods as they are served at meal times for chemical analysis. Because of the labour and difficulties involved, this method has been little used and only in small-scale surveys; for example, to study the diets of hospital patients and nurses (King Edward's Hospital Fund for London, 1943). The duplicate portions are not taken by a child whose diet is being studied, but by his mother or an investigator.

It was originally hoped that the methods of survey developed by McHenry and his colleagues (Riggs, Perry, Patterson, Leeson, Mosley \& McHenry, 1943; Leeson, Crawford, Webb, Swan, Davey, Clarke \& McHenry, 1946) and by Donelson \& Leichsenring (1942, 1945) could have been included in the study, but practical difficulties did not permit this.

\section{METHODS}

\section{Collection of data by the four survey methods}

National Children's Home. The children live in 'families' in separate 'houses', each 'family' consisting of about twenty children, ranging from infants to adolescents of both sexes, in the care of a sister and deputy sister. The study was limited to five children aged 10-1 5 years in ten 'houses', that is, fifty children in all", the diet of each child being recorded for 3 days. The work was planned so that the results from the four methods could be compared on exactly the same diets. The following is an example of the procedure. The words in brackets refer to the four methods of survey described on pp. 89-90.

For breakfast a child might have porridge, bread and butter and a cup of cocoa. The porridge bowl was put on the scales and the point of the scales set to zero. The porridge was measured into the bowl in tablespoons and these were recorded (homely measures). The porridge was then weighed (weighing). An equal weight of porridge was then taken and put into the Kilner jar for analysis (chemical analysis). The number of slices of bread a child ate was recorded (homely measures), and each slice weighed (weighing), and then duplicates were put into the Kilner jar (chemical analysis). The amount of butter used by each child was weighed each day and a duplicate weight put into the Kilner jar for each day. For the cocoa, the cup was put on the scale, the pointer set to zero, the cocoa poured in and the amount recorded in cupfuls (homely measures), and weighed (weighing). The scale pointer was set back to zero, the sugar was put in the cocoa in teaspoons (homely measures) and weighed (weighing). Duplicate amounts of sugar and cocoa were then put into the Kilner jar for analysis (chemical analysis). Each evening the children were asked to describe the food they had eaten during the previous $24 \mathrm{hr}$. (questioning), that is, the food already recorded by weighing and homely measures and duplicated for chemical analysis.

- Chemical analysis was not done for one child and the nutrient tables are therefore based on data for forty-nine children. 
The Kilner jars containing the duplicates were put into a refrigerator immediately after each meal, and each 3 rd day were taken to the Laboratory of the Government Chemist. The work at the National Children's Home was supervised by Dr G. Wagner, Miss L. E. Patrick and Miss M. Costain. The survey was made in November and December 1946.

It is believed that the survey in the National Children's Home gave a satisfactory comparison of weighing, homely measures and chemical analysis as methods of survey. It was not a satisfactory test of the questioning method as this would usually operate, since the children took a lively interest in the proceedings and familiarized themselves with their food more than is usual. The results are, however, presented, as they show that, under the conditions of the test, close agreement can be attained between the results of weighing and questioning. The work at Ealing was done to compare those two methods under field conditions.

Ealing schoolchildren. The survey was limited to boys aged 12 years because it was believed that children of that age would be suitable subjects for such an investigation. On each of 3 successive days diet histories for the previous $24 \mathrm{hr}$. were procured by questioning. The survey as eventually carried out differed in some respects from that planned. It was intended to divide the children into three groups: $(I)$ to be questioned in school without any previous preparation or notification that the inquiry was to be made; (2) to be told that the inquiry was to be made and asked to make notes during their meals on the amount of food eaten, to aid them when questioned; and (3) to be questioned as in (2), the mothers to record by weighing the food eaten by the children during the test period. Shortly before the beginning of the inquiry a letter was sent to the mothers of the children explaining what was required, together with forms for the making of notes on the foods eaten. These forms were to be taken to school by the children and used as memory aids at the interview. Social investigators were to visit the mothers who were to weigh food, to aid them in their part of the investigation.

As the children in the three groups were to be randomly selected the results would have given comparisons between weighing and questioning with and without memory aids. Further, the information given by the child at the interview and that recorded by the mother in the home could have been compared for each child in the third group. In practice, however, the two sets of information could not satisfactorily be gathered from group 3 , since a large proportion of the children remembered the weights of the foods they had eaten, and this interfered with the normal progress of the interview. For this reason the only information from group 3 used in the investigation was that recorded by the mothers. The children were questioned in school by Miss $\mathrm{K}$. Chamberlain and Miss R. Harrison, who had had a good deal of experience of the method, and the homes of the children of group 3 were visited by Miss R. Russell and Mrs F. Kelenyi of the Social Survey.

Diet histories of twenty-eight children were obtained by questioning with memory aids, of twenty-eight by questioning without memory aids, and of thirty-two by weighing. The survey was made during October 1947. 


\section{Chemical analysis of the diets}

The chemical analyses described were made in the Department of the Government Chemist under the direction of two of the authors (C.G.D. and J.K.). An account follows of the methods of sampling and of estimating moisture, ash, iron, calcium, nitrogen, fat, sugar and starch.

\section{Preparation of material for analysis}

Each sample of food received for analysis consisted of the entire diet of one child for 3 days and was contained in some six $4 \mathrm{lb}$. Kilner jars. A single day's food usually occupied two jars and was appropriately labelled, but for the purpose of this investigation all the food taken in 3 days was bulked as follows. Each jar was weighed as received, the contents were tipped into a large aluminium container and the jar weighed empty. In this way the complete sample of food was mixed in one vessel and its weight determined. At this stage, materials such as prunes containing stones were dissected with a stainless-steel knife, and hard fibrous material cut into pieces to facilitate reduction to a uniform paste at the next stage. Bones, fruit stones, and similar material of no dietetic value were rejected. In practice the quantity rejected was small and the final analyses were expressed in terms of the total weight of food received.

The whole of the food was then introduced, in portions, into a Waring Blendor to produce a homogenized product. This was transferred to a second aluminium container for final mixing. Throughout the whole of the mixing and averaging operations, special precautions were maintained to avoid contamination with iron and calcium. Where the liquid in the mixed food was not sufficient for the Blendor to operate properly, a known weight of water was added to bring the mixture to a suitable consistency.

From this prepared sample a suitable portion was removed and stored in a refrigerator until analysed, since at this stage the material tended to forment rapidly at room temperature. The original samples were also kept in a refrigerator until preparation could commence. Where possible, analysis was started immediately.

\section{Moisture content}

Methods for the determination of moisture in certain specified foodstuffs have been studied by many workers (Johnson, 1945; Levy, Murtaugh \& Rosenblatt, 1945; McCance, Widdowson \& Shackleton, 1938; Monier-Williams, 1941; Porter \& Willits, 1944; Riddle, 1944; Walker, 1946), but no special attention has been paid to mixed meals.

Experiments showed that drying at $100^{\circ}$ under the conditions detailed below was sufficient to bring the dry matter from the mixed diets to constant weight, and that there was a further loss of only $\mathrm{r} \%$ on raising the temperature to $135^{\circ}$.

Method. About $25 \mathrm{~g}$. of the prepared sample, accurately weighed, were placed in a metal dish fitted with a perforated lid, given a preliminary drying on a steam-bath and finally heated for $4 \mathrm{r} h$ r. in an electric oven at $100^{\circ}$. The material was weighed after cooling for $\mathrm{I} \mathrm{hr}$. in a desiccator, and the loss of weight was recorded as moisture. 
Total ash

Method. About $20 \mathrm{~g}$. of the prepared sample were first dried at $100^{\circ}$ in a tared silica dish and then heated at $500^{\circ}$ in an electric muffle till the ash was white. After cooling, the dish and contents were weighed for total ash. This ash was then prepared for the determination of iron and calcium by treatment with $5 \mathrm{ml} .5 \mathrm{~N}-\mathrm{HCl}$ and the mixture evaporated almost to dryness on the steam-bath. The residue was dissolved by boiling with $10 \mathrm{ml} .0 .5 \mathrm{~N}-\mathrm{HCl}$ and the solution filtered into a $100 \mathrm{ml}$. graduated flask. The dish was washed with three further $10 \mathrm{ml}$. portions of boiling $0.5 \mathrm{~N}-\mathrm{HCl}$ and the washings passed through the same filter. When cold the combined extracts were made up with $0.5 \mathrm{~N}-\mathrm{HCl}$ to $100 \mathrm{ml}$.

\section{Iron}

This metal was determined by the 0 -phenanthroline method (Saywell \& Cunningham, 1937) as modified by Pringle (1946) and others. The advantages of this method are as follows: it is specific for iron; the intensity of the colour produced remains constant for several days; errors due to the presence of phosphate and variation of $\mathrm{pH}$ are avoided; and the optimum transmittance occurs in a part of the spectrum in which spectrophotometers employing the selenium barrier-layer type of cell are sensitive, and where the intensity of the colour produced obeys Beer's law.

Method. A ro ml. portion of the acid extract of the total ash was pipetted into a $15 \mathrm{ml}$. graduated flask and $\mathrm{I} \mathrm{ml}$. of a $2 \%(\mathrm{w} / \mathrm{v})$ solution of sulphur dioxide in water added. The colour was developed by the addition of $5 \mathrm{ml}$. of sodium acetate buffer to give a $\mathrm{pH}$ of 3.5 and of $1 \mathrm{ml}$. of a $0.23 \%$ solution of $o$-phenanthroline in water. The solution was made up to volume and allowed to stand overnight; the colour was then recorded and compared against a standard calibration graph, a correction for the 'blank' being made if necessary.

\section{Calcium}

The calcium content was determined by the early micromethod of Kramer \& Tisdall (1921) in modified form (Association of Official Agricultural Chemists, r945a; McCance \& Shipp, 1933). By this method the calcium is precipitated as oxalate, centrifuged, washed, dissolved in acid and titrated with $0.01 \mathrm{~N}$-potassium permanganate, the whole operation being carried out in one tube to avoid losses by manipulation.

Method. A $5 \mathrm{ml}$. portion of the acid extract of the total ash was pipetted into a Io ml. centrifuge tube, $0.2 \mathrm{ml}$. of $0.02 \%$ phenol-red solution added and $6 \mathrm{~N}-\mathrm{NH}_{4} \mathrm{OH}$ run in till the solution just turned purple red. This was followed by sufficient glacial acetic acid to produce a bright yellow colour.

The solution was made up to $6.5 \mathrm{ml}$. with water, and $\mathrm{I} \cdot 5 \mathrm{ml}$. saturated ammonium oxalate solution were added to precipitate calcium oxalate. After standing $\mathrm{I} \mathrm{hr}$. the oxalate was centrifuged, washed with $5 \mathrm{ml} .0 .3 \mathrm{~N}-\mathrm{NH}_{4} \mathrm{OH}$ until free from soluble oxalate and dissolved in $\mathrm{I} \mathrm{ml} .4 \mathrm{~N}-\mathrm{H}_{2} \mathrm{SO}_{4}$. The tube and contents were heated in a boiling water-bath for a few minutes and titrated with $0.01 \mathrm{~N}$-potassium permanganate. 
Nitrogen

This was estimated by the Kjeldahl process, employing the technique critically reviewed by Alcock (1946) and based on that described in the Fertiliser and Feeding Stuffs Act (Great Britain Parliament, I928).

Method. About $5^{-6} \mathrm{~g}$. of the prepared sample, accurately weighed, were heated with $10 \mathrm{~g}$. anhydrous $\mathrm{Na}_{2} \mathrm{SO}_{4}$, about $0.2 \mathrm{~g}$. $\mathrm{CuSO}_{4} \cdot 5 \mathrm{H}_{2} \mathrm{O}$ and $25 \mathrm{ml}$. conc. $\mathrm{H}_{2} \mathrm{SO}_{4}$ until a perfectly clear solution of a pale blue colour was obtained; the heating was then continued for I hr.

In the subsequent steam distillation, after addition of excess ION-NaOH, $400 \mathrm{ml}$. of distillate were collected in a flask containing excess $0.1 \mathrm{~N}-\mathrm{HCl}$ and back-titrated with $0 \cdot 1 \mathrm{~N}-\mathrm{NaOH}$, using methyl red indicator.

Fat

Various methods have been developed for the extraction of fat from foods, including direct extraction from the dried product by solvents, saponification of the fat followed by extraction of the liberated fatty acids by light petroleum, and acid treatment followed by extraction with mixed ethers.

The first method (McCance \& Shipp, 1933) fails to extract the fat completely from many cooked starchy foods, such as bread and biscuit. In the second method (Liebermann \& Szekely, 1898a,b) the calculation of the fat content rests on the assumption that triglycerides are the only compounds of fatty acids present in the material originally taken. Further, it is admitted that the light petroleum takes up sterols as well as fatty acids and that steps should be taken for their removal. Leathes \& Raper (1925) and others have introduced modifications to this end. It is unlikely that any of the fats encountered in this investigation would contain more than a trace of such substances.

The presence of lower fatty acids in butter, margarine and the hydrogenated coconut oil used in biscuit making, however, introduces errors, since these acids are appreciably volatile under the conditions required to drive off the extracting solvent and to dry the recovered fatty acids. Further, as butyric acid is miscible.with water, and other acids are appreciably soluble in it, they are not completely extracted by solvents.

The choice of the correct conversion factor for fatty acids to fat is a matter of some difficulty, since fats such as whale oil have an appreciably higher mean molecular weight than coconut oil and butterfat. Without an exact knowledge of the nature of all the fats in a meal, the factor can be given only approximately, except where the fatty acids are non-volatile and a titration can be made so as to obtain the mean molecular weight.

The third method, and that adopted for this investigation, is that described in the British Standard no. 770 (British Standards Institution, 1938). It consists in treating the sample with hydrochloric acid followed by alcohol and extracting the fat with ethyl ether and light petroleum. The technique has been widely used since its acceptance by the Rome Conference in 1930 and its adoption in principle by the Association of Official Agricultural Chemists ( $1945 b$ ) for the determination of fat in foods. The extract obtained by this method includes glycerides, phosphatides, sterols and free fatty acids. 
Method. About $5 \mathrm{~g}$. of the prepared sample were accurately weighed into the standard fat-extraction tube, $15 \mathrm{ml}$. of conc. $\mathrm{HCl}$ were added and the mixture was gently boiled to effect solution of as much material as possible. Then $10 \mathrm{ml}$. of industrial methylated spirit were added, the fluids mixed and cooled, $25 \mathrm{ml}$. ethyl ether added and the stoppered tube was vigorously shaken. After addition of $25 \mathrm{ml}$. of light petroleum the tube was again shaken. The mixture was separated into two layers by centrifuging, and the upper layer was blown off and collected in a tared beaker. The extraction was repeated and the combined extracts were evaporated and dried to constant weight at $100^{\circ}$.

The residue was extracted with light petroleum and the beaker containing any insoluble matter dried at $100^{\circ}$ and reweighed. The difference in weight was reported as fat. The analytical precautions detailed in the British Standard no. 770 (British Standards Institution, $193^{8}$ ) were observed.

\section{Available carbohydrate}

The term 'available carbohydrate' as applied to foods is used to denote sugar, starch and its degradation products which the body is capable of utilizing. This may differ from the total carbohydrate obtained by 'difference'. methods of chemical analysis and from the carbohydrate utilized by other animal organisms (Maynard, 1944).

Our knowledge of the correlation between biological values and values obtained by chemical analysis for carbohydrates which have been altered by cooking is incomplete, and it is known that some animals utilize certain carbohydrates more completely than the human organism.

Recent work has shown that certain organic acids, such as may be derived from fruit, are utilized within the body in the same way as the more complex carbohydrates, but in the present investigation no account was taken of this, since the amount present was small.

The literature on nutrition contains many data giving analyses of individual foods, both cooked and uncooked, including figures for available carbohydrate. Unfortunately, the analytical procedures used vary considerably. Little information is available on the analysis of mixed foods, and there are significant gaps in our knowledge of the effect of cooking on starch.

In considering the most suitable method for the determination of starch in this investigation, it was borne in mind that cooked cereals contain a variety of substances such as dextrins, hemicelluloses, pentosans, cellulose and fibre, all of which may be attacked to some extent by reagents to give glucose or other copper-reducing substances. Further, starch is not always readily extracted from certain foods.

The methods devised for the determination of starch may be divided into nonhydrolytic and hydrolytic, and these have been fully discussed by several workers (Browne \& Zerban, I94I ; Etheredge, r94I ; Radley, 1943). The apparent disadvantage of hydrolytic methods which employ acid rests in the fact that by such treatment nonstarchy carbohydrates may be broken down to give copper-reducing bodies of doubtful biological value. Hydrolysis by enzymes, on the other hand, may not be sufficiently 
selective, nor is the constitution of the degradation products accurately known. It was decided, therefore, to investigate three methods for the determination of starch depending on entirely different principles: hydrolysis by takadiastase, solubilization by calcium chloride, and extraction and hydrolysis to sugars by hydrochloric acid.

(I) Hydrolysis by takadiastase. The takadiastase method described by McCance et al. (1938) depends on the conversion of starch to a mixture of maltose and glucose and the subsequent determination of these mixed sugars by ferricyanide, using a suitable conversion factor. The authors, in their discussion of the method, make this observation: 'Takadiastase solution alone has a considerable reducing action on alkaline ferricyanide and this reduction may amount to nearly half the total reduction obtained after hydrolysis of the starch.... Later it was shown by the preparation of a glucosazone that some at any rate of the reducing power of the takadiastase was due to glucose or fructose.' The takadiastase used by these workers appears to have been the type used medicinally, reduced to a certain starch conversion value by the addition of lactose, which would account for the high 'blank'. By using a specimen adjusted with talc the 'blank' was reduced to a negligible figure.

The calculation of the amount of starch present from the sugar found depends on a constant maltose : glucose ratio of $3: \mathrm{I}$ in the product of hydrolysis, but experiments did not confirm this ratio, and it may well be that in cooked food the starch degradation products are not acted upon by the enzyme in the same way as uncooked starch.

The reliability of the alkaline ferricyanide method for the determination of the sugars produced from starch is also open to question; a useful comment on this subject is given by Hanes (1929). Comparative experiments using the ferricyanide method and the Fehling method developed by Lane \& Eynon (1923) gave lower results by the latter technique.

Another complication is that the amount of enzyme used, the time of incubation, the degree of grinding and the volume of solution all affect the degree of degradation of the starch to sugar.

The instruction in the McCance method that if iodine gives a blue colour with the residue after incubation the determination must be discarded may involve considerable loss of time and material. Further, there appears to be no ready means of assessing the significance of any blue colour which in turn may be masked or modified by colours given by the action of iodine on non-starchy material present.

(2) Solubilization by calcium chloride. The solubilization method has been developed by Clendenning (1942, 1943a, b, 1945 $a, b, c, d$ ). Starchy material is dissolved in a solution of calcium chloride, protein precipitated by stannic chloride and the starch content of the clear filtrate determined polarimetrically. The $(\alpha)_{D}^{20^{\circ}}$ for starch is taken to be $+203^{\circ}$.

This method gave a solution which was difficult to filter and required up to $24 \mathrm{hr}$. for the collection of sufficient liquid. The extent of recovery was checked by extraction of maize starch, flour, bread and boiled potato (Table $\mathrm{I}$ ). The maize starch was completely recoverable, but the yield from the other foods did not agree with the figure deduced by difference. Results, however, were reproducible.

When the method was applied to experimental meals (Table 2), figures were generally 
obtained in agreement with those from alternative methods, but on occasion the results were unduly low. This irregularity appeared to be due to some undetermined factor.

(3) Extraction and hydrolysis to sugars by hydrochloric acid. According to Fraps (1932), starch and pentosans can be extracted from cereals by $0.02 \mathrm{~N}-\mathrm{HCl}$ without simultaneous hydrolysis, but when the filtered extract is heated with more concen-

Table I. Starch values obtained by different methods for certain foods

\begin{tabular}{|c|c|c|c|c|c|c|c|}
\hline \multirow[b]{2}{*}{ Food } & \multirow[b]{2}{*}{$\begin{array}{l}\text { Moisture } \\
\text { (g./100 g.) }\end{array}$} & \multirow[b]{2}{*}{$\begin{array}{c}\text { Ash } \\
(\mathrm{g} / 100 \mathrm{~g} .)\end{array}$} & \multirow[b]{2}{*}{$\begin{array}{l}\text { Protein } \\
\text { (g./100 g.) }\end{array}$} & \multicolumn{4}{|c|}{ Starch } \\
\hline & & & & $\begin{array}{c}\text { 'By } \\
\text { difference' } \\
\text { (g./100 g.) }\end{array}$ & $\begin{array}{c}\mathrm{CaCl}_{\mathrm{g}} \\
\text { method } \\
\text { (g./ } 100 \mathrm{~g} .)\end{array}$ & $\begin{array}{c}\text { Taka- } \\
\text { diastase } \\
\text { method } \dagger \\
\text { (g./100 g.) }\end{array}$ & $\begin{array}{c}\mathrm{O} \cdot \mathrm{O} 2 \\
\mathrm{~N}-\mathrm{HCl} \\
\text { method } \\
\text { (g. } / 100 \mathrm{~g} .)\end{array}$ \\
\hline Maize starch & $\mathrm{II} \cdot 8$ & 0.1 & - & $89 \cdot 1$ & 87.9 & - & $87 \cdot 0$ \\
\hline Flour & 12.4 & 0.9 & $13.5 \ddagger$ & $73 \cdot 2$ & 63.5 & $58 \cdot I$ & $66 \cdot 4$ \\
\hline Bread & 3.6 & 2.9 & $13.7 \ddagger$ & $79 \cdot 8$ & $63 \cdot 2$ & $59 \cdot 5$ & $70 \cdot 0$ \\
\hline Boiled potato & 14.1 & $2 \cdot 1$ & $6 \cdot 6 \S$ & $77 \cdot 2$ & $54 \cdot 3$ & - & $7 \times \cdot 1$ \\
\hline
\end{tabular}

- Starch $(\alpha)_{D}^{20}=+203^{\circ}$.

$\uparrow$ Factor 0.91 used to convert sugar, found by Fehling titration, to starch.

I Factor $\mathrm{N} \times 5.7$.

$\S$ Factor $\mathrm{N} \times 6.25$.

Table 2. Starch values obtained by different methods for mixed meals

\begin{tabular}{|c|c|c|c|c|c|}
\hline \multirow[b]{2}{*}{ Meal } & \multirow{2}{*}{$\begin{array}{c}\mathrm{CaCl}_{2} \\
\text { method } \\
\text { (g./100 g.) }\end{array}$} & \multicolumn{2}{|c|}{ Takadiastase method } & \multirow{2}{*}{$\begin{array}{l}\text { A.O.A.C. } \\
\text { method" } \\
\text { (g./100 g.) }\end{array}$} & \multirow{2}{*}{$\begin{array}{c}0.02 \\
\mathrm{~N}-\mathrm{HCl} \\
\text { method } \\
\text { (g./100 g. }\end{array}$} \\
\hline & & $\begin{array}{l}\text { Ferricyanide } \\
(\mathrm{g} . / \mathrm{/00} \mathrm{g} .)\end{array}$ & $\begin{array}{c}\text { Fehling } \\
\text { (g./100 g.) }\end{array}$ & & \\
\hline $\begin{array}{l}\mathbf{A} \\
\mathbf{B} \\
\mathbf{C}\end{array}$ & $\begin{array}{l}59 \cdot 0 \\
58 \cdot 2 \\
60 \cdot 6\end{array}$ & $\begin{array}{l}76 \cdot 0 \\
74 \cdot 5 \\
76 \cdot 5\end{array}$ & $\begin{array}{l}57 \cdot 5 \\
57 \cdot 7 \\
61: 0\end{array}$ & $\begin{array}{l}65 \cdot 1 \\
66 \cdot 3 \\
66 \cdot 3\end{array}$ & $\begin{array}{l}63 \cdot 0 \\
62 \cdot 0 \\
62 \cdot 2\end{array}$ \\
\hline
\end{tabular}

trated $\mathrm{HCl}$ they are converted into sugars and may be estimated by a suitable copperreduction method. This method differs from that of the Association of Official Agricultural Chemists (1945c) which uses one strength of acid.

The acid extraction method has the advantages of being rapid and of leaving a residue giving no blue colour with iodine. The figures obtained for starch in the experimental meals were, as might be expected, somewhat lower than those given by the A.O.A.C. method, no doubt because the weaker acid was more selective in the preliminary separation of starch from other bodies.

This method of Fraps (1932), in our experience, gave the most reproducible results and was free from the objections described in the two other methods. It was therefore adopted in the absence of any method in which direct correlation has been secured between the calorie value obtained by a chemical method and that obtained in the human subject.

It is considered that of the methods compared, the $0.02 \mathrm{~N}-\mathrm{HCl}$ method, subsequently adopted for this investigation, gives results which are probably nearer the true total of starch plus its 'available' degradation products than any other method at present 
available. Since the analytical work recorded above was completed, two further papers on the determination of starch by its conversion to dextrose have appeared (Lampitt, Fuller \& Goldenberg, 1947; Lampitt, Fuller, Goldenberg \& Green, 1947).

\section{Sugar}

The total sugar was determined by the method described by McCance et al. (1938), with a few modifications. These included the Government Laboratory method for Fehling titration to eliminate the variable in the technique of Lane \& Eynon (1923) and the use of hydrochloric acid in place of citric acid for inversion.

Method. Thirty g. of the prepared sample were stood overnight with $100 \mathrm{ml}$. industrial methylated spirit; the mixture was then transferred to a soxhlet thimble with the aid of hot alcohol. The excess liquid percolating through the thimble was collected and set on one side. The contents of the thimble were extracted with alcohol for 16 $24 \mathrm{hr}$. and the extract, combined with that obtained above, evaporated on a steam-bath to about $10 \mathrm{ml}$. The residue in the thimble was dried at $100^{\circ}$, weighed, finely ground and set aside for the estimation of starch. Check experiments confirmed that no sugar was present in the extracted material. The concentrated extract was transferred with the aid of a little water to a $150 \mathrm{ml}$. graduated flask, the solution nearly neutralized to litmus with $0.1 \mathrm{~N}$-caustic soda, and basic lead acetate solution added till no more precipitate formed. The mixture was allowed to stand for $10 \mathrm{~min}$., sufficient saturated sodium phosphate $\left(\mathrm{Na}_{2} \mathrm{HPO}_{4}\right)$ solution was added to remove all lead, the liquid was made up to the mark, shaken and filtered through a dry fluted filter, the first runnings being rejected. Of the bright filtrate $40 \mathrm{ml}$. were pipetted into a $100 \mathrm{ml}$. flask with $6 \mathrm{ml} .6 \cdot 34 \mathrm{~N}-\mathrm{HCl}$, and the mixture immersed in a water-bath at $60^{\circ}$ for $12 \mathrm{~min}$. The flask was then cooled, the liquid made nearly neutral to litmus with $5 \mathrm{~N}$-caustic soda and made up to $100 \mathrm{ml}$. with water.

Ten ml. of Fehling's solution were pipetted into a $250 \mathrm{ml}$. Pyrex conical flask, $40 \mathrm{ml}$. water and a pinch of pumice powder added and the whole brought to the boil. A known volume of the sugar solution was run in from a burette and one or two drops of methylene blue solution were added. Further additions of the sugar solution were made, keeping the liquid boiling, until the colour of the methylene blue was discharged. An indication was thus obtained of the volume of sugar solution required. The determination was then repeated, running in all but $\mathrm{I} \mathrm{ml}$. of the predetermined volume of sugar solution together with sufficient water to ensure that the final volume at the end of the titration would be $75 \mathrm{ml}$. The mixture was brought to the boil and allowed to boil for exactly $2 \mathrm{~min}$.; then one or two drops of methylene blue solution were added and the titration was completed in a further $1 \frac{1}{2} \mathrm{~min}$.

In an exactly similar way ro ml. of Fehling's solution were standardized against a $0.1 \%$ solution of invert sugar.

\section{Starch}

The starch was determined in the dry powdered extract from the sugar estimation above.

Method. A $0.4 \mathrm{~g}$. portion was weighed into a $150 \mathrm{ml}$. conical flask and brought to 
the boil with $5 \circ \mathrm{ml}$. water; $2 \mathrm{ml} .0 .5 \mathrm{~N}-\mathrm{HCl}$ were added and the boiling was continued under a reflux for $30 \mathrm{~min}$. The liquid was then filtered by suction and the filtrate and hot-water washings made up to approx. $100 \mathrm{ml}$. and transferred to a $200 \mathrm{ml}$. graduated flask. After adding $7.6 \mathrm{ml}$. conc. $\mathrm{HCl}$, the flask and contents were heated in a boiling water-bath for $2 \frac{1}{2} \mathrm{hr}$., cooled and made up to $200 \mathrm{ml}$, and the sugar content was determined by titration against $\mathrm{ro} \mathrm{ml}$. Fehling's solution using the technique described for sugar.

\section{Food tables}

The nutrients in the diets recorded at the National Children's Home and at Ealing were calculated from food tables based on values given in Nutritive Values of Wartime Foods (Accessory Food Factors Committee, 1945) and The Chemical Composition of Foods (McCance \& Widdowson, 1946), and from values of made-up dishes based on recipes adapted to the food supplies available at the time.

It must be emphasized at this stage that the purpose of the investigation was to compare the results obtained by different methods of individual survey and not to compare or assess the basic data in tables of food composition or to discuss methods of calculating the energy values of foods or diets. Hence the method of calculating the composition and energy value of the diet on this occasion was the same as that usually employed by one of us (E.R.B.). The intention was to compare composition as estimated by chemical analysis and as calculated, by the same set of tables, from the quantities of foods recorded by three survey methods. An unexpected difficulty arose in respect of 'available carbohydrates' in the analyses. In preliminary studies the method used by McCance et al. (1938) to estimate starch gave values $21 \%$ greater on the average than the acid-hydrolysis method finally selected for use in this inquiry. In order, therefore, that the comparison of results might as far as possible be confined to differences between survey methods, the starch values estimated by analysis were increased by $21 \%$.

\section{RESULTS}

Table 3 shows the results of the chemical analysis of the diets of forty-nine individual children. Tables $4-9$ give the survey results obtained in the National Children's Home and Tables 10 and $I I$ those obtained in Ealing. Table 4 shows the average daily amounts of foods consumed, as found by weighing, recording in homely measures, and questioning, and Table 5 the average daily energy and nutrient intakes found by the four methods. Table 6 shows for energy and for each nutrient the average percentage differences between the methods, and Table 7 the frequency distribution of those differences for the individual children. Table 8. gives the correlation coefficients between the energy and nutrient values found by the four methods. Table 9 shows the energy and nutrient values found for forty-nine individual children by weighing. Tables 10 and II show the average daily food intakes and energy and nutrient intakes obtained in Ealing by weighing and questioning with or without memory aids.

National Children's Home. The average daily amounts of foods grouped as in Table 4 are of the same order for the three methods, but agreement is on the whole closer 
Table 3. Average daily intake of nutrients by forty-nine children as determined by chemical analysis

\begin{tabular}{|c|c|c|c|c|c|c|c|c|c|c|}
\hline $\begin{array}{c}\text { Child's } \\
\text { code } \\
\text { no." }\end{array}$ & Sex & $\begin{array}{c}\text { Age } \\
\text { (years) }\end{array}$ & $\begin{array}{c}\text { Food } \\
\text { as con- } \\
\text { sumed } \\
(\mathrm{g} .)\end{array}$ & $\begin{array}{l}\text { Dry } \\
\text { food } \\
\text { (g.) }\end{array}$ & $\begin{array}{l}\text { Fat } \\
\text { (g.) }\end{array}$ & $\begin{array}{c}\text { Nitro- } \\
\text { gen } \\
\text { (g.) }\end{array}$ & $\begin{array}{l}\text { Sugar } \\
\text { (as } \\
\text { glucose) } \\
\text { (g.) }\end{array}$ & $\begin{array}{c}\text { Starch } \\
\text { (as } \\
\text { starch) } \\
\text { (g.) }\end{array}$ & $\begin{array}{l}\text { Calcium } \\
\text { (mg.) }\end{array}$ & $\begin{array}{l}\text { Iron } \\
\text { (mg.) }\end{array}$ \\
\hline I & $\mathrm{F}$. & 14 & 1625 & 466 & $94 \cdot 8$ & II 8 & $73 \cdot 3$ & 140.5 & 830 & 14.5 \\
\hline 2 & F. & 12 & 2813 & 713 & 102.0 & $16 \cdot 3$ & 185.5 & $229 \cdot 5$ & 1520 & $24 \cdot 2$ \\
\hline 3 & F. & 13 & 1716 & 463 & $80 \cdot 2$ & $11 \cdot 8$ & $77 \cdot 4$ & 162.8 & 908 & $13^{\circ} 0$ \\
\hline 4 & F. & 13 & 2240 & 542 & $83 \cdot 0$ & $12 \cdot 8$ & $15 x \cdot 2$ & $136 \cdot 6$ & 1110 & 16.8 \\
\hline 5 & F. & 15 & 2036 & 517 & $108 \cdot 1$ & 14.6 & 115.0 & $131 \cdot 4$ & 1180 & $15^{\circ} 0$ \\
\hline 6 & F. & 15 & 1615 & 508 & $98 \cdot 1$ & 12.5 & I IO'I & $148 \cdot 9$ & 972 & 14.2 \\
\hline 7 & F. & 13 & 2617 & 707 & $106 \cdot 9$ & $18 \cdot 9$ & $145^{\circ} \circ$ & $244 \cdot 2$ & 1725 & $26 \cdot 2$ \\
\hline 8 & F. & 13 & 1670 & 497 & $102 \cdot 8$ & $x 2 \cdot 2$ & $98 \cdot x$ & $162 \cdot 0$ & 1087 & 13.9 \\
\hline 9 & F. & 12 & 2943 & 707 & $86 \cdot 3$ & $18 \cdot 0$ & $129 \cdot 3$ & $257 \cdot 2$ & I 500 & $21 \cdot 9$ \\
\hline 10 & F. & 14 & 2192 & 598 & $93^{\circ} 9$ & $15 \cdot 1$ & 95.0 & 197.2 & 1333 & 19.7 \\
\hline II & M. & 12 & 2406 & 598 & 85.0 & $16 \cdot 8$ & 105.9 & 147.9 & 1130 & 19.7 \\
\hline 12 & F. & 15 & 1840 & 470 & $62 \cdot 5$ & 13.0 & $91 \cdot 1$ & 179.5 & 897 & 16.0 \\
\hline 13 & M. & 13 & 2262 & 640 & $102 \cdot 2$ & $18 \cdot 2$ & $92 \cdot 0$ & 227.9 & I080 & $22 \cdot 4$ \\
\hline 14 & M. & 12 & 2723 & 735 & $100 \cdot 0$ & $19 \cdot 3$ & 100.8 & $260 \cdot 0$ & I 280 & $24 \cdot 2$ \\
\hline is & M. & 12 & 2468 & 581 & $108 \cdot 8$ & 15.4 & $100 \cdot 0$ & 174.4 & II 50 & 19.8 \\
\hline 16 & M. & 13 & $25^{86}$ & 682 & $85 \cdot 3$ & 17.9 & 103.0 & 237.5 & 1289 & $2 I \cdot 8$ \\
\hline 17 & F. & 14 & 1414 & 457 & $73 \cdot 2$ & 10.8 & 70.5 & 170.0 & 714 & $14^{\circ} 2$ \\
\hline 18 & F. & 14 & $153^{6}$ & 396 & $62 \cdot 7$ & $8 \cdot 5$ & 115.8 & 110.5 & 682 & $12 \cdot 9$ \\
\hline 19 & F. & 13 & 1431 & 455 & 65.5 & 12.5 & $72 \cdot 5$ & 169.0 & 720 & 16.4 \\
\hline 20 & F. & 13 & 1745 & 498 & $79 \cdot 8$ & 12.5 & $97 \cdot 3$ & $168 \cdot 0$ & 785 & 17.5 \\
\hline 21 & M. & 13 & 2423 & 615 & 85.0 & $18 \cdot 5$ & 106.2 & $234^{\circ} \circ$ & 1400 & 19.1 \\
\hline 22 & M. & 12 & 2546 & 616 & 103.0 & 14.8 & $151 \cdot 6$ & 201.0 & 1270 & $19 \cdot 1$ \\
\hline 23 & M. & 12 & 2444 & 597 & . 90.8 & $14 \cdot 6$ & 135.4 & 182.5 & 1265 & $22 \cdot 6$ \\
\hline 24 & M. & 13 & 2396 & 615 & 74.5 & 15.9 & $82 \cdot 5$ & $23^{8 \cdot 2}$ & 1410 & $19 \cdot 1$ \\
\hline 25 & M. & 12 & 2506 & 659 & 83.0 & 19.4 & $106 \cdot 0$ & 220.9 & 1304 & 20.4 \\
\hline 26 & M. & 13 & 2668 & 737 & $87 \cdot 8$ & $20 \cdot 6$ & $78 \cdot 0$ & 312.0 & 1435 & $22 \cdot 1$ \\
\hline 27 & M. & 12 & 2257 & 603 & $79 \cdot 0$ & 14.5 & 147.9 & 192.0 & 1220 & 19.9 \\
\hline 28 & M. & 13 & 2322 & 606 & 86.0 & $\times 4 \cdot 6$ & $144^{\circ} 0$ & $181 \cdot 9$ & 1204 & $\times 9.4$ \\
\hline 29 & M. & 13 & 2373 & 705 & $91 \cdot 5$ & 18.4 & $88 \cdot 0$ & $2120^{\circ}$ & 1260 & $20 \cdot 4$ \\
\hline 30 & M. & I3 & 2166 & 568 & 70.9 & 16.0 & $83 \cdot 9$ & $235 \circ$ & 974 & $18 \cdot 5$ \\
\hline 31 & M. & 12 & $180 \mathrm{I}$ & 520 & 65.5 & $13 \cdot 1$ & 89.0 & $209 \cdot 5$ & 843 & 16.6 \\
\hline 32 & M. & 12 & 1764 & 514 & $67 \cdot 8$ & 14.2 & $82 \cdot 8$ & $1720^{\circ}$ & 806 & $15^{\circ} 9$ \\
\hline 33 & M. & 12 & 1848 & 497 & 66.5 & 14.1 & 93.0 & 151.5 & 885 & 19.4 \\
\hline 34 & M. & 12 & 1858 & 517 & $73^{\circ} 0^{\circ}$ & I5. I & $80 \cdot 7$ & $206 \cdot 9$ & 916 & $16 \cdot 6$ \\
\hline 35 & M. & 12 & 2135 & 537 & $67 \cdot 8$ & 16.2 & $78 \cdot 0$ & $209 \cdot 5$ & 1069 & $18 \cdot 8$ \\
\hline 36 & M. & 13 & 2482 & 614 & $79 \cdot 3$ & $\times 8 \cdot 2$ & $84 \cdot 2$ & $254^{\circ} 5$ & 1165 & 23.4 \\
\hline 37 & M. & 12 & 2372 & 600 & $82 \cdot 2$ & $17 \cdot 4$ & $78 \cdot 5$ & $256 \cdot 5$ & 1140 & $20 \cdot 4$ \\
\hline $3^{8}$ & M. & 12 & 2312 & 554 & $64 \cdot 1$ & 16.0 & 85.4 & .240 .0 & 1085 & 19.5 \\
\hline 39 & M. & 12 & 2376 & 583 & $71 \cdot 0$ & 15.7 & $77 \cdot 5$ & $242 \cdot 0$ & I I I I & $20 \cdot 4$ \\
\hline 40 & F. & 10 & 1327 & 384 & 66.5 & 10.0 & 81.0 & $131 \cdot 8$ & 834 & 15.7 \\
\hline 41 & F. & 12 & 1845 & 448 & $69 \cdot 1$ & 117 & $92 \cdot 5$ & 145.2 & 1050 & $17 \cdot 5$ \\
\hline 42 & F. & 13 & 1462 & 403 & $5+3$ & $9 \cdot 4$ & 80.8 & 149.1 & 976 & 13.7 \\
\hline 43 & F. & II & 1700 & 455 & 76.5 & 12.7 & $97 \cdot 5$ & 163.9 & 1082 & $17 \cdot 3$ \\
\hline 44 & F. & 12 & 1838 & 478 & $62 \cdot 6$ & II $\cdot 8$ & $108 \cdot 0$ & 172.0 & 1065 & 17.4 \\
\hline 45 & M. & 13 & 1717 & 496 & $88 \cdot 4$ & $14^{\cdot 1}$ & $77 \cdot 0$ & $145^{\circ} \circ$ & 968 & $17 \cdot 4$ \\
\hline 46 & M. & 13 & 1866 & 555 & 75.0 & 14.8 & 75.5 & 172.0 & 988 & $18 \cdot 3$ \\
\hline 47 & M. & 13 & 1832 & $55^{8}$ & $62 \cdot 0$ & 15.9 & $71 \cdot 0$ & 216.5 & 977 & 19.5 \\
\hline 48 & M. & 12 & $176_{3}$ & 518 & $72 \cdot 0$ & 13.9 & 80.4 & $192 \cdot 3$ & 944 & $17 \cdot 1$ \\
\hline 49 & M. & 13 & 1732 & 530 & $72 \cdot 6$ & I 3.8 & $81 \cdot 6$ & $194^{\circ} 0$ & 1006 & $17 \cdot 5$ \\
\hline
\end{tabular}

- The same code numbers have been used in this table as in Table 9. Thus the data for child no. I in this table can be compared with those for child no. 1 in Table 9, and so on. 
between weighing and questioning than between weighing and homely measures. The differences between the average consumptions found by weighing and homely measures are $26 \%$ for meat, bacon and fish, $31 \%$ for meat or fish pies, $15 \%$ for puddings, $29 \%$ for fruit and $31 \%$ for eggs. Nearly all the groups listed in Table 4 include a number of individual foods, for some of which greater differences occurred than appear from the group data.

\section{Table 4. Average daily intake of foods found by three methods of survey in the National Children's Home, Harpenden}

\begin{tabular}{lccc} 
& \multicolumn{3}{c}{ Method of survey } \\
\cline { 2 - 3 } \multicolumn{1}{c}{ Food } & \multicolumn{3}{c}{ Homely } \\
Measures & Questioning \\
Meat, bacon and fish (oz.) & $2 \cdot 7$ & 3.4 & 2.6 \\
Meat, fish pies and puddings (oz.) & 3.6 & 4.7 & 3.3 \\
Cheese dishes (oz.) & 0.6 & 0.5 & 0.4 \\
Puddings (oz.) & 7.2 & 8.3 & 6.8 \\
Potatoes (oz.) & 4.6 & 4.4 & 4.2 \\
Vegetables (oz.) & 2.5 & 2.8 & 2.3 \\
Fruit (oz.) & 1.7 & 2.2 & 1.7 \\
Bread and other cereals (oz.) & 15.1 & 14.0 & 15.1 \\
Cheese (oz.) & 0.12 & 0.15 & 0.11 \\
Eggs (no.) & 0.26 & 0.34 & 0.30 \\
Sugar (oz.) & 0.88 & 0.97 & 0.79 \\
Preserves (oz.) & 1.09 & 0.95 & 0.90 \\
Fats (oz.) & 0.90 & 1.00 & 1.00 \\
Milk (pt.) & 0.65 & 0.70 & 0.65
\end{tabular}

Table 5. Average daily energy and nutrient intakes found by four methods of survey in the National Children's Home, Harpenden

\begin{tabular}{|c|c|c|c|c|c|c|c|c|}
\hline \multirow[b]{3}{*}{ Item } & \multicolumn{8}{|c|}{ Method of survey } \\
\hline & \multicolumn{2}{|c|}{ Weighing } & \multicolumn{2}{|c|}{ Homely measures } & \multicolumn{2}{|c|}{ Questioning } & \multicolumn{2}{|c|}{ Chemical analysis } \\
\hline & Value & s.D.* & Value & S.D.* & Value & S.D.* & Value & S.D.* \\
\hline $\begin{array}{l}\text { Calories (Cal.) } \\
\text { Protein (g.) }\end{array}$ & $\begin{array}{r}2660 \\
83\end{array}$ & $\begin{array}{r}507 \\
18\end{array}$ & $\begin{array}{r}2771 \\
89\end{array}$ & $\begin{array}{r}423 \\
16\end{array}$ & $\begin{array}{r}2607 \\
81\end{array}$ & $\begin{array}{r}487 \\
18\end{array}$ & $\begin{array}{l}2381 \\
89 t\end{array}$ & $\begin{array}{r}218 \\
16\end{array}$ \\
\hline Fat (g.) & 96 & 22 & 107 & $2 I$ & 95 & 19 & 81 & 14 \\
\hline Carbohydrate (g.) & 366 & 69 & 363 & 52 & 357 & 68 & $324 t$ & 39 \\
\hline Calcium (g.) & $1 \cdot 3$ & 0.33 & $1 \cdot 3$ & 0.28 & $\mathrm{I} \cdot \mathbf{2}$ & 0.33 & $\mathbf{I} \cdot \mathbf{I}$ & 0.23 \\
\hline Iron (mg.) & 15 & 3.3 & 16 & $3 \cdot 9$ & 15 & $3 \cdot 1$ & 19 & $3 \cdot 1$ \\
\hline
\end{tabular}

- These are standard deviations for a single child and were calculated from the actual 3 day intakes of nutrients, the resulting values being divided by 3 to obtain the above figures.

$\dagger$ Protein $=N \times 6 \cdot 0$, as the diets contain both animal and cereal protein.

I The starch values determined by the method adopted were increased by $21 \%$ to permit comparison between analytical and calculated results.

The nutrient values obtained by the four methods and presented in Tables 5 and 6 show that, compared with the values found by chemical analysis, the three other methods overestimate for all nutrients except iron, for which there is an underestimate, and for protein, for which there is an underestimate by weighing and questioning, and no difference by homely measures. Even by the presumed most reliable method, 
i.e. weighing, the overestimate for calories is $11-12 \%$. Compared with weighing, the homely measures method gives an overestimate for calories and all nutrients except carbohydrate, and questioning an underestimate for calories and all nutrients except fat. Although most of the differences between weighing and the two other methods are significant, they are, on the whole, small.

Table 7 shows that for individual diets there are considerable differences between the values obtained for energy and nutrients by analysis and by calculation from food tables. For example, if the results obtained by chemical analysis and by weighing the

Table 6. Percentage differences between the average energy and nutrient values obtained by four methods of survey in the National Children's Home, Harpenden

\begin{tabular}{|c|c|c|c|c|c|c|c|c|c|c|}
\hline \multirow[b]{2}{*}{ Item } & \multicolumn{2}{|c|}{$\frac{W-A}{A}$} & \multicolumn{2}{|c|}{$\frac{H-A}{A}$} & \multicolumn{2}{|c|}{$\frac{Q-A}{A}$} & \multicolumn{2}{|c|}{$\frac{H-W}{W}$} & \multicolumn{2}{|c|}{$\frac{Q-W}{W}$} \\
\hline & $\begin{array}{l}\text { Differ- } \\
\text { ence }\end{array}$ & S.D. & $\begin{array}{l}\text { Differ- } \\
\text { ence }\end{array}$ & S.D. & $\begin{array}{l}\text { Differ- } \\
\text { ence }\end{array}$ & S.D. & $\begin{array}{l}\text { Differ- } \\
\text { ence }\end{array}$ & S.D. & $\begin{array}{l}\text { Differ- } \\
\text { ence }\end{array}$ & S.D. \\
\hline $\begin{array}{l}\text { Calories } \\
\text { Protein }\end{array}$ & $\begin{array}{r}11 \\
-6\end{array}$ & $\begin{array}{l}I \cdot I \\
0.8\end{array}$ & $\begin{array}{r}17 \\
1\end{array}$ & $\begin{array}{l}1 \cdot 2 \\
1 \cdot 4\end{array}$ & $\begin{array}{r}9 \\
-9\end{array}$ & $\begin{array}{l}1 \cdot 3 \\
1 \cdot 3\end{array}$ & $\begin{array}{l}5 \\
8\end{array}$ & $\begin{array}{l}0.7 \\
1.0\end{array}$ & $\begin{array}{l}-2 \\
-3\end{array}$ & $\begin{array}{l}1 \cdot 0 \\
1.0\end{array}$ \\
\hline & 20 & 2.4 & 34 & $2 \cdot 6$ & 19 & 2.5 & 12 & I.O & 0 & 1.4 \\
\hline Carbohydrate & 13 & $1 \cdot 4$ & 14 & $1 \cdot 7$ & II & $1 \cdot 7$ & 0 & 0.8 & -2 & $1 \cdot 1$ \\
\hline Calcium & 15 & $x \cdot 5$ & 22 & $1 \cdot 8$ & 10 & 1.8 & 6 & $1 \cdot 0$ & -5 & $1 \cdot 0$ \\
\hline Iron & -18 & 1.5 & -10 & $2 \cdot 2$ & -20 & 1.6 & 9 & $1 \cdot 2$ & -2 & $x \cdot 2$ \\
\hline
\end{tabular}

$W=$ weighing, $Q=$ questioning, $H=$ homely measures, $A=$ chemical analysis, $8 . D .=$ standard deviation.

Note. The percentage differences shown in the tables are the averages of the percentage differences between the values found by the various methods of survey. The values in Table 5 are straightforward arithmetical averages of the values found for the different nutrients by the four methods. Hence the percentage differences shown in this table need not be the same as those calculated from Table 5 .

forty-nine diets are compared, the differences exceed ro\% in twenty diets for protein, thirty-seven for fat, twenty-three for carbohydrate, thirty-three for calories, thirtyfive for calcium and thirty-seven for iron; and for one, twenty-nine, twelve, eight, twenty-four and twenty-six of these, respectively, the differences exceed $20 \%$. The same picture is obtained from comparison of the values found by chemical analysis and by questioning and homely measures.

The correlation coefficients (Table 8) between the nutrient values obtained by weighing, questioning and homely measures are high, from 0.85 to 0.97 . Those between the values obtained by chemical analysis and the three other methods are also high for calories $(0.80-0.87)$, protein $(0.82-0.92)$, carbohydrate $(0.7 \mathrm{I}-0.8 \mathrm{I})$ and calcium $(0.78-0.85)$, but fairly low for fat $(0.43-0.57)$ and for iron $(0.38-0.6 \mathrm{I})$. This shows that for energy and all nutrients, except fat and iron, the ranking of the values is about the same with all four methods. For fat and iron the lack of conformity arises in respect of chemical analysis versus the rest.

Ealing. The results of the Ealing survey (Tables 10 and $\mathrm{II}$ ) show that the average daily amounts of foods as found by weighing and questioning with and without memory aids are, in general, of the same order, although there is an overestimate of 39 or $62 \%$ for potatoes by questioning without or with memory aids. The same average nutrient 
intakes were found by questioning with and without memory aids, but compared with weighing there was an overestimate of $10 \%$ for calories, $12-13 \%$ for protein, $12-14 \%$ for carbohydrate and $11-16 \%$ for iron.

Table 7. Distribution of the percentage differences between the energy and nutrient values found by four methods of survey for forty-nine children in the National Children's Home, Harpenden

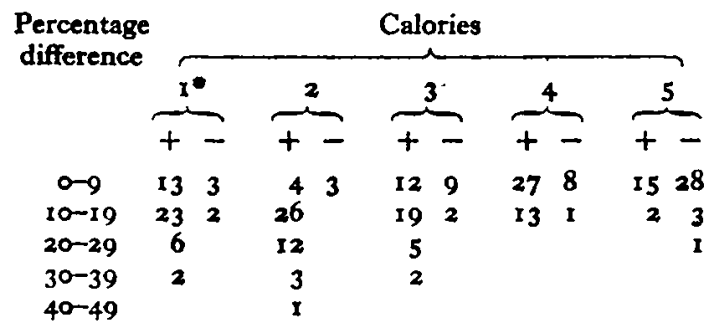

Fat

\begin{tabular}{|c|c|c|c|c|c|c|c|c|c|c|}
\hline & 3 & $x$ & & & & & 4 & t & 5 & \\
\hline & + & - & + & - & + & - & + & - & + & - \\
\hline $0-9$ & 9 & 3 & 4 & 2 & 6 & 7 & 17 & 3 & I3 & 21 \\
\hline $10-19$ & 4 & 4 & 3 & I & 8 & 2 & 19 & & 7 & 6 \\
\hline $20-29$ & II & & 7 & I & 7 & I & 10 & & I & I \\
\hline $30-39$ & 10 & I & 7 & & 5 & I & & & & \\
\hline $40-49$ & 4 & & 12 & & 9 & & & & & . \\
\hline $50+$ & 3 & & 12 & & 3 & & & & & \\
\hline
\end{tabular}

Calcium

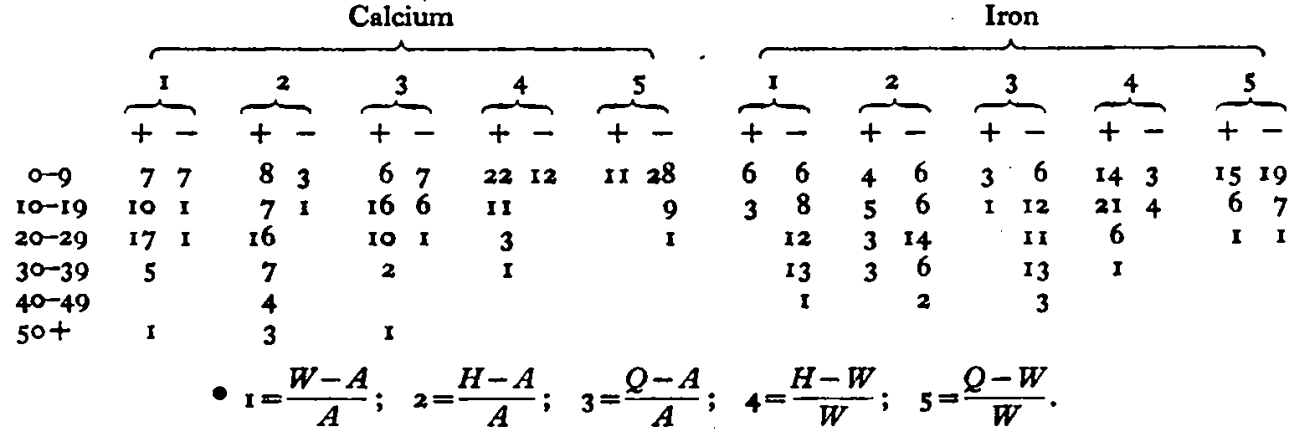

$W=$ weighing, $Q=$ questioning, $H=$ homely measures, $A=$ chemical analysis.

Table 8. Correlation coefficients between energy and nutrient values found by four methods of dietary survey in the National Children's Home, Harpenden

$\begin{array}{ccccccc}\begin{array}{c}\text { Quantities } \\ \text { correlated }\end{array} & \text { Calories } & \text { Protein } & \text { Fat } & \begin{array}{c}\text { Carbo- } \\ \text { hydrate }\end{array} & \text { Calcium } & \text { Iron } \\ W \times H & 0.94 & 0.90 & 0.93 & 0.93 & 0.97 & 0.90 \\ W \times Q & 0.94 & 0.94 & 0.91 & 0.93 & 0.97 & 0.91 \\ W \times A & 0.87 & 0.92 & 0.57 & 0.81 & 0.85 & 0.57 \\ H \times Q & 0.91 & 0.87 & 0.87 & 0.91 & 0.94 & 0.85 \\ H \times A & 0.85 & 0.82 & 0.53 & 0.71 & 0.78 & 0.38 \\ Q \times A & 0.80 & 0.88 & 0.43 & 0.75 & 0.84 & 0.61\end{array}$

\footnotetext{
$W=$ weighing, $Q=$ questioning, $H=$ homely measures, $A=$ chemical analysis.
} 
Table 9. Individual average daily energy and nutrient intakes of forty-nine children in the National Children's Home, Harpenden, as found by the zveighing method of survey and calculations from food tables

\begin{tabular}{|c|c|c|c|c|c|c|}
\hline $\begin{array}{l}\text { Child's } \\
\text { code no." }\end{array}$ & $\begin{array}{l}\text { Calories } \\
\text { (Cal.) }\end{array}$ & $\begin{array}{l}\text { Protein } \\
\text { (g.) }\end{array}$ & $\begin{array}{l}\text { Fat } \\
\text { (g.) }\end{array}$ & $\begin{array}{c}\text { Carbohydrate } \\
\text { (g.) }\end{array}$ & $\begin{array}{l}\text { Calcium } \\
\text { (mg.) }\end{array}$ & $\begin{array}{l}\text { Iron } \\
\text { (mg.) }\end{array}$ \\
\hline I & 2117 & $65 \cdot 5$ & $85 \cdot 0$ & $272 \cdot 4$ & 871 & 15.5 \\
\hline 2 & $346 I$ & 103.5 & $139^{\circ} 9$ & $446 \cdot 9$ & 2023 & 15.4 \\
\hline 3 & 1924 & $57 \cdot 3$ & $67 \cdot 2$ & $272 \cdot 5$ & 790 & $13 \cdot 1$ \\
\hline 4 & 2583 & $81 \cdot 8$ & $92 \cdot 1$ & $356 \cdot 6$ & 1360 & 14.2 \\
\hline 5 & 2474 & $76 \cdot 9$ & 103.2 & $309 \cdot 4$ & I I 53 & r6.8 \\
\hline 6 & 2147 & $69 \cdot 0$ & $82 \cdot 3$ & $282 \cdot 6$ & 941 & $16 \cdot 5$ \\
\hline $\begin{array}{l}7 \\
8\end{array}$ & $\begin{array}{l}3342 \\
2062\end{array}$ & $\begin{array}{r}109.1 \\
64.9\end{array}$ & $\begin{array}{r}\times 34.9 \\
70.3\end{array}$ & $\begin{array}{l}422 \cdot 9 \\
292 \cdot 3\end{array}$ & $\begin{array}{r}1669 \\
859\end{array}$ & $\begin{array}{l}19.5 \\
15.6\end{array}$ \\
\hline 9 & 3351 & $101 \cdot 6$ & I $31 \cdot 9$ & $439 \cdot 4$ & 1775 & $18 \cdot 2$ \\
\hline 10 & 2352 & $78 \cdot 4$ & $86 \cdot 7$ & 314.4 & 1360 & $13 \cdot 7$ \\
\hline 11 & 3149 & $105 \cdot 4$ & $108 \cdot 4$ & $437 \cdot 9$ & 1442 & $21 \cdot 2$ \\
\hline 12 & 2313 & $68 \cdot 2$ & $82 \cdot 9$ & $323 \cdot 4$ & 1072 & I $x \cdot 5$ \\
\hline 13 & 3224 & $117 \cdot 2$ & $108 \cdot 3$ & $445 \cdot 2$ & 1375 & $23 \cdot 1$ \\
\hline I 4 & 3796 & 124.4 & $136 \cdot 6$ & $517 \cdot 3$ & 1714 & 23.7 \\
\hline 15 & 3000 & $101 \cdot 9$ & $115 \cdot 2$ & 388.8 & 1471 & $18 \cdot 1$ \\
\hline I6 & $344^{6}$ & $115 \cdot 2$ & 110.5 & $497 \cdot 6$ & 1531 & $22 \cdot 6$ \\
\hline 17 & 2264 & $65 \cdot 9$ & $90 \cdot 0$ & $297 \cdot 6$ & 921 & $12 \cdot 0$ \\
\hline 18 & 2079 & $49 \cdot 3$ & $82 \cdot 0$ & 285.9 & 803 & $8 \cdot 5$ \\
\hline 19 & 2236 & $68 \cdot 7$ & $88 \cdot 7$ & $290 \cdot 8$ & 951 & 12.4 \\
\hline 20 & 2495 & $69 \cdot 7$ & $1090^{\circ}$ & $308 \cdot 7$ & 916 & $12 \cdot 8$ \\
\hline 2 I & 3175 & 107.7 & $121 \cdot 0$ & 413.9 & 1683 & $15 \cdot 1$ \\
\hline 22 & 2874 & $77 \cdot 5$ & 10377 & $407 \cdot 7$ & 1412 & $12 \cdot 3$ \\
\hline 23 & 2865 & $8 \mathrm{I} \cdot \mathrm{I}$ & $116 \cdot 9$ & $372 \cdot 2$ & I433 & $12 \cdot 2$ \\
\hline 24 & 3168 & $95 \cdot 6$ & $114 \cdot 5$ & $43^{8 \cdot 7}$ & 1744 & 14.4 \\
\hline 25 & 3156 & $100 \cdot 1$ & $118 \cdot 5$ & $422 \cdot 3$ & 1755 & $14 \cdot 1$ \\
\hline 26 & 3861 & $\operatorname{III} \cdot 2$ & $158 \cdot 0$ & $498 \cdot 6$ & 1915 & $17 \cdot 0$ \\
\hline 27 & 2823 & $75 \cdot 1$ & $112 \cdot 4$ & 377.7 & I3Io & I $2 \cdot 1$ \\
\hline 28 & 2760 & $79 \cdot 5$ & 112.4 & $357 \cdot 7$ & 1290 & $12 \cdot 6$ \\
\hline 29 & 3645 & 104.9 & $132 \cdot 0$ & $509 \cdot 3$ & 2005 & $16 \cdot 2$ \\
\hline 30 & 2802 & $87 \cdot 0$ & 90.8 & $409 \cdot 1$ & 1247 & $17 \cdot 7$ \\
\hline 31 & 2439 & $72 \cdot 3$ & $79^{\circ} 9$ & 3577 & $99 \mathrm{I}$ & 15.9 \\
\hline 32 & 2498 & $74 \cdot 6$ & $8 r \cdot 6$ & $366 \cdot 3$ & 1071 & $16 \cdot 3$ \\
\hline 33 & 2371 & $74 \cdot 8$ & $77 \cdot 4$ & $343 \cdot 8$ & 1080 & 14.8 \\
\hline 34 & 24 II & $80 \cdot 2$ & $79^{\circ} \mathrm{I}$ & 344.5 & I 178 & $16 \cdot 3$ \\
\hline 35 & 2572 & $92 \cdot 9$ & $82 \cdot 0$ & $3^{6} \cdot 6$ & 1319 & $16 \cdot 6$ \\
\hline $3^{6}$ & 2908 & $101 \cdot 7$ & $91 \cdot 9$ & $418 \cdot 6$ & 1438 & $18 \cdot 0$ \\
\hline 37 & 2960 & roI'5 & 834 & 450.9 & 1405 & $18 \cdot 6$ \\
\hline 38 & 2703 & $96 \cdot 6$ & $88 \cdot 0$ & $3^{8} I \cdot I$ & 1390 & 16.5 \\
\hline 39 & 2753 & $95 \cdot 7$ & $9 x \cdot 8$ & $3^{86 \cdot 1}$ & 1329 & $17 \cdot 0$ \\
\hline 40 & 1791 & $55 \cdot 7$ & 66.7 & $242 \cdot 0$ & 927 & $10 \cdot 0$ \\
\hline $4 I$ & 2026 & 66.4 & $76 \cdot 8$ & 267.4 & 1257 & 10.6 \\
\hline 42 & 2016 & 60.4 & $69 \cdot 3$ & $287 \cdot 6$ & 894 & $11 \cdot I$ \\
\hline 43 & 2166 & $67 \cdot 7$ & $78 \cdot 7$ & $296 \cdot 6$ & 1125 & II'5 \\
\hline 44 & 2281 & $68 \cdot 5$ & $80 \cdot 2$ & $321 \cdot 4$ & 1178 & $12 \cdot 2$ \\
\hline 45 & 2267 & $68 \cdot 7$ & $77 \cdot 8$ & $323^{\circ} 0$ & 893 & $12 \cdot 1$ \\
\hline 46 & 2368 & $72 \cdot 2$ & $75^{\circ} \circ$ & $351 \cdot 0$ & 950 & $12 \cdot 8$ \\
\hline 47 & $247 I$ & $75 \cdot 7$ & 82.9 & 355.4 & 987 & $13 \cdot 3$ \\
\hline 48 & 2335 & $71 \cdot 4$ & $77 \cdot 8$ & $337 \cdot 4$ & 955 & $12 \cdot 2$ \\
\hline 49 & 2396 & $72 \cdot 0$ & $78 \cdot 3$ & 350.9 & 950 & 12.5 \\
\hline
\end{tabular}

- The same code numbers have been used in this table as in Table 3. Thus the data for child no. I in this table can be compared with those for child no. $\mathrm{I}$ in Table 3 , and so on. 


\section{DISCUSSION}

There is little information in the literature on the accuracy of methods of individual survey, although a number of statements of a broad character has been made from time to time. Wiehl (1944) says of questioning: 'Although the method is approximate it is

Table 10. Average daily intake of foods determined by different survey methods for Ealing boys aged 12 years*

\begin{tabular}{|c|c|c|c|}
\hline \multirow[b]{3}{*}{ Food } & \multicolumn{3}{|c|}{ Method of survey } \\
\hline & \multirow[b]{2}{*}{ Weighing } & \multicolumn{2}{|c|}{ Questioning } \\
\hline & & No memory aids & Memory aids \\
\hline Meat, bacon and fish (oz.) & 3.5 & $3 \cdot 2$ & $\begin{array}{l}4.0 \\
0.6\end{array}$ \\
\hline Puddings (oz.) & $5 \cdot 3$ & 5.5 & 5.6 \\
\hline Potatoes (oz.) & $7 \cdot 2$ & $10 \cdot 0$ & 117 \\
\hline Vegetables (oz.) & $3 \cdot 2$ & $2 \cdot 8$ & $3 \cdot 0$ \\
\hline Fruit (oz.). & $6 \cdot 7$ & 6.5 & $5 \cdot 8$ \\
\hline Bread, cakes and porridge (oz.) & $26 \cdot 3$ & 17.8 & $17 \cdot 7$ \\
\hline Cheese (oz.) & 0.2 & 0.3 & 0.3 \\
\hline Eggs (no.) & 0.2 & 0.3 & 0.2 \\
\hline Sugar (oz.) & I.8 & $1 \cdot 5$ & 1.4 \\
\hline Preserves (oz.) & $1 \cdot 1$ & $x \cdot 7$ & 1.6 \\
\hline Butter (oz.) & $x \cdot f$ & $1 \cdot 7$ & $x \cdot 5$ \\
\hline Milk (pt.) & $0 . t$ & 0.73 & 0.73 \\
\hline
\end{tabular}

- Weighing, 32 boys; questioning, 28 boys in each case.

Table 11. Average daily intake of energy and nutrients determined by different survey methods for Ealing boys aged 12 years*

\begin{tabular}{|c|c|c|c|c|}
\hline \multicolumn{3}{|c|}{ Method of survey } & & \\
\hline \multirow[b]{3}{*}{$\begin{array}{l}\text { Weighing } \\
\text { (I) }\end{array}$} & \multicolumn{2}{|c|}{ Questioning } & & \\
\hline & \multirow{2}{*}{$\begin{array}{l}\text { No } \\
\text { memory aids } \\
\text { (2) }\end{array}$} & \multirow[b]{2}{*}{$\begin{array}{l}\text { Memory aids } \\
\text { (3) }\end{array}$} & \multicolumn{2}{|c|}{ Percentage difference } \\
\hline & & & $(2)-(1)$ & $(3)-(1)$ \\
\hline 2776 & 3041 & 3054 & rot & rot \\
\hline 75 & 84 & 85 & $12 \dagger$ & 13t \\
\hline 104 & 109 & 106 & 5 & 2 \\
\hline 385 & $43 I$ & 440 & $12 \dagger$ & $14 t$ \\
\hline $\mathrm{I} \cdot \mathrm{I}$ & $x \cdot 3$ & $x \cdot 3$ & 18 & 18 \\
\hline $14 \cdot 8$ & $16 \cdot 5$ & $17 \cdot 2$ & II & $16 \dagger$ \\
\hline
\end{tabular}

- Weighing, 32 boys; questioning, 28 boys in each case.

$\uparrow$ Difference significant.

believed that the estimate of food intake is reasonably accurate', and Chattaway et al. (1946) say: 'A high degree of precision cannot be attributed to the results of this survey, but, on the basis of work carried out with our students, it seems that most of the estimates are accurate to $\pm 10 \%$ ' For homely measures, Bransby \& Wagner (1945) report: 'Trials have shown that the average intake for groups of children found by this method tended to be just slightly greater than those found by the precise 
technique.' Commenting on the possible inaccuracy of their method, McHenry, Ferguson \& Gurland (1945) say: 'Previous work has indicated that this error is not likely to exceed $10 \%$.'

Widdowson \& McCance (1943), reviewing comparisons of calculated and analytical values for diets, reported that, on the whole, the consensus of opinion seemed to be that analytical values for nitrogen agreed fairly closely with those calculated; values for calcium calculated from Sherman's tables tended to be higher than the corresponding values determined by direct analysis; agreement for phosphorus was usually better than that for calcium; and for iron the agreement was not so good. They presented data for six subjects comparing the values for protein, fat, calcium, phosphorus and iron obtained by analysis and by calculation, and found that average values agreed closely for all nutrients. For protein, fat and calcium, however, two of the six pairs of values, for phosphorus one, and for iron three, differed by more than $10 \%$. They also showed that up to $200 \mathrm{mg}$. daily of calcium might be obtained from drinking water in districts where the water is very hard, which would not, of course, be included when food tables were used, and that the iron intakes might sometimes be a good deal higher than those calculated from food tables because of additions from cooking utensils. They concluded, however, that for individual mixed diets the results obtained by chemical analysis and by calculation from food tables were sufficiently close to warrant the use of food tables in dietary surveys. McHenry and his colleagues compared the calculated and chemically determined values for a number of dinners and found that the mean differences for calories, protein and fat were $-6,-1.4$ and $13.7 \%$, respectively. For iron the calculated contents varied from -35 to $244 \%$ of the determined values, with an average error of $27 \%$, and for calcium the values determined, compared with those calculated, ranged from 59 to 121,68 to 142 and 65 to $131 \%$, according to the food tables used. The mean analytical values ranged from 86 to $94 \%$. of the values found by calculation (Patterson \& McHenry, x94I; Young \& McHenry, 1943 $a, b$; Semmons \& McHenry, 1944).

The results of the present inquiry fall into two parts, consumption in terms of foods and consumption in terms of nutrients. Results for the consumption of foods, grouped as in Table 4, as found by the three methods, weighing, questioning and homely measures, are of the same order, although there are substantial differences for individual foods. Modification of the procedure in the light of the data from this inquiry and from unpublished work should bring the results obtained by weighing and homely measures into closer agreement. But no survey method which gives substantial errors in the estimated weights of individual foods and of which the apparent accuracy depends on those errors cancelling each other out, can be considered satisfactory, even if the error in the final result is small.

The differences between the average nutrient values found by calculation and analysis are due, first, to differences between the methods adopted for the chemical analysis of the diets and those used to obtain the values in the food tables; secondly, to the inclusion of values in the food tables which do not correspond to the dishesserved; and thirdly, to lack of precision in the methods of survey. The first and second are reflected in the differences between the values obtained by chemical analysis and by 
weighing, and the third in those between weighing on the one hand and questioning and homely measures on the other. The considerable differences in nutrient values determined by the methods of analysis adopted by different workers raise important issues concerning the compilation of food tables. The fact that the inquiry was made in an institution may have introduced some systematic deviations from standard values for foods. For example, the milk supplied may have been of low fat content, the meat may have been well trimmed of fat, and the values used for made-up dishes may have differed widely from the true values. Grant (1944) has shown how substantial such differences may be. But, whatever the reason, the fact remains that there was a considerable overestimate by calculation from tables as compared with chemical analysis.

In regard to the third reason listed above, i.e. errors due to the method of survey, although the average nutrient values obtained by weighing, by questioning and by homely measures were in broad agreement, questioning and recording in homely measures gave overestimates compared with weighing. Previous experimental work (Bransby, unpublished) also showed that homely measures gave an overestimate. In 1942 ten housewives recorded their diets, excluding bread and milk, for $\mathrm{I}$ week, by weighing and in homely measures. The same values were obtained by both methods for protein and fat, but the homely measures overestimated by $7,3,3$, and $3 \%$ for carbohydrate, calories, calcium and iron, respectively. In 1944, eighteen housewives of different ages and economic groups measured their food, except bread, for I week, again by weighing and homely measures. - It was found that homely measures overestimated by $9 \%$ for calories and by $13,5,8$ and $12 \%$ for animal protein, vegetable protein, calcium and iron, respectively.

This raises the question of what differences are allowable between analytical values and those found by calculation from the results of any dietary survey. In this respect calories differ from the nutrients for which standards of requirement have been proposed. The calorie requirements suggested by expert committees represent the amounts required by different groups of the population to maintain health and working capacity. No safety margin is allowed. Liberal additions have been made to the estimated requirements of most nutrients considered, so that an estimate of energy intake must be more closely scrutinized than estimates of such other components of the diet. The overestimate of $I I-12 \%$ for energy intake by calculation, as opposed to analysis, is of the same order as, for example, the difference between allowances for successive age groups. It is therefore too large to be ignored if comparison with requirements is to be made. On the other hand, it does not preclude calculation from tables if the purpose is to compare the energy intakes of different groups at the same time, or of the same group at different times, with a view to discovering improvement or deterioration.

Concerning estimates of the nutritive values of individual diets, the present inquiry shows that the differences between the values found by chemical analysis and by calculation from food tables are in a high proportion of cases so large as to throw serious doubts on the reliance which can be placed on the values obtained by calculation. The results obtained by questioning are of special interest, as general impressions suggest that the method is inexact and that the resulting error must be large. The results from the National Children's Home show, in fact, that, under certain conditions, 
the values may be in very close agreement with those obtained by weighing, and those from Ealing suggest that they may be close even under field conditions. Questioning has the attraction of being easy and rapid, as is illustrated by the survey in Ealing in which two field workers, working long hours, were able to visit only sixteen women a day in their homes to check weighing, while two dietitians between them interviewed daily over forty children in school to obtain diet histories by questioning. Field trials are required to ascertain to which groups of the population the method, or some modification of it, may be applied.

In view of the need for information on the precision which can be attached to the results of different methods of individual dietary survey, it is suggested that, before any new survey method is used, it should undergo field trials, the results of which should be published. Data should be included to show, for example, whether a method is suitable simply to ascertain the broad levels of consumption, or whether it can be used for more precise work, and to what population groups it can be applied. It is probable that in the past survey methods have sometimes been applied to groups of the population for which they are not suitable. For example, it is doubtful whether the questioning method can be used satisfactorily to study the diets of children aged 8 years, as it was used by Chattaway et al. (r946). More exact definition of the uses and limitations of the different methods of individual survey would be of great service to those who wish to make dietary investigations.

\section{SUMMARY}

I. A comparison was made of the estimates of the food and nutrient intakes for 3 days of a number of children, some living in an institution and some living at home, obtained by four methods of individual dietary survey, namely, weighing, questioning, homely measures, and chemical analysis.

2. Duplicates of the diets eaten by each child during each of the 3 days of survey were collected for chemical analysis. The diets for the 3 days were mixed and samples analysed for moisture, ash, calcium, iron, nitrogen, fat, sugar and starch. As the intention of the inquiry was to compare nutrients as estimated by chemical analysis and as calculated, with the same set of food tables, from the quantities of foods recorded by the three survey methods, and as the method used by McCance et al. (1938) to estimate starch gave values $21 \%$ greater on the average than the acid-hydrolysis methods selected for use in this inquiry, the starch values found by chemical analysis were increased by $21 \%$, in order that the comparison of results might as far as possible be confined to differences between survey methods.

3. When foods of similar kind were combined into groups, the average consumptions found by the weighing, questioning and homely measures methods were in broad agreement, but there were substantial differences for individual foods between the amounts found by weighing as compared with the two other methods.

4. The average energy and nutrient values found by the weighing, questioning and homely measures methods were in good agreement, but compared with the values found by chemical analysis, each method gave a considerable overestimate for calories, fat, carbohydrate and calcium and an underestimate for iron. 
5. A high proportion of comparisons for individual diets showed differences between the values found by calculation from food tables and by chemical analysis sufficiently great to throw serious doubt on the reliance which can be placed on energy and nutrient values obtained by calculation from food tables.

One of the authors (E,R.B.) wishes to express his appreciation both to Mr E. E. Shutt and his staff at the National Children's Home, Harpenden, and to Dr R. A. Leader, Medical Officer of Health, Ealing, for the facilities they placed at his disposal and the valuable help they gave throughout the inquiry. The field work was done by Dr G. Wagner, Miss K. Chamberlain, Miss M. Costain, Miss R. Harrison, Mrs F. Kelenyi, Miss L. E. Patrick and Miss R. Russell, and he is grateful to them for doing this so ably. Miss Chamberlain, Miss Costain and Miss Harrison are members of the staff of the Scientific Adviser's Division, Ministry of Food, and he wishes to thank Dr Magnus Pyke for allowing him their services. He is also grateful to Major B. B. MacIchan and Miss W. Taylor of the War Office for a large amount of Hollerith work and to $\mathrm{Dr} \mathrm{H}$. O. Hartley for advice on statistical methods.

Two of the authors (C.G.D., J.K.) wish to thank the Government Chemist for permission to publish the analytical details given in the paper, and to express their appreciation of the co-operation of several members of the laboratory staff.

\section{REFERENCES}

Accessory Food Factors Committee (1945). War Memor. med. Res. Coun., Lond., no. 14.

Alcock, R. S. (1946). Analyst, 7x, 233.

Association of Official Agricultural Chemists (1945a). Official and Tentative Methods of Analysis, 6th ed., p. 119. Washington: Association of Official Agricultural Chemists.

Association of Official Agricultural Chemists (1945b). Official and Tentative Methods of Analysis, 6th ed., p. 263. Washington: Association of Official Agricultural Chemists.

Association of Official Agricultural Chemists (1945c). Official and Tentative Methods of Analysis, 6th ed., p. 410. Washington: Association of Official Agricultural Chemists.

Bransby, E. R. \& Wagner, G. (1945). Brit. med. F. ii, 682.

British Standards Institution (1938). British Standard, no. 770.

Browne, C. A. \& Zerban, F. W. (194r). Sugar Analysis, 3rd ed. London: Chapman and Hall.

Chattaway, F. W., Happold, F. C. \& Happold, M. A. (1946). Brit. med. F. i, 429.

Clendenning, K. A. (1942). Canad. $\mathcal{F}$. Res. 20 (C), 403.

Clendenning, K. A. (1943a). Canad. F. Res. 21 (C), I73.

Clendenning, K. A. (1943 b). Canad. F. Res. 21 (C), 323.

Clendenning, K. A. (1945a). Canad. F. Res. 23 (B), I I3.

Clendenning, K. A. (1945b). Canad. F. Res. 23 (B), 131.

Clendenning, K. A. (I945C). Carad. F. Res. 23 (B), 239.

Clendenning, K. A. (1945d). Canad. F. Res. 23 (F), 155.

Donelson, E. G. \& Leichsenring, J. M. (1942). Ұ. Amer. diet. Ass. 18, 429.

Donelson, E. G. \& Leichsenring, J. M. (1945). F. Amer. diet. Ass. 21, 440.

Etheredge, M. P. (1941). F. Ass. off. agric. Chem., Wash., 24, 113.

Fowke, H. M. (r945). Proc. Nutr. Soc. 3, 28.

Fraps, G. S. (1932). F. Ass. off. agric. Chem., Wash., 15, 304.

Grant, M. (1944). Nature, Lond., 154, 485.

Great Britain Parliament (1928). The Fertilisers and Feeding Stuffs Regulations, Statutory Rules and Orders, 1928, no. 421 .

Hanes, C. S. (1929). Biochem. F. 23, 99.

Johnson, C. M. (1945). Industr. Engng Chem. (Anal. ed.), r7, 312.

King Edward's Hospital Fund for London (1943). Memorandum on Hospital Diet. London: Geo. Barber and Son Ltd.

Kramer, B. \& Tisdall, F. F. (1921). F. biol. Chem. 48, I. 
Lampitt, L. H., Fuller, C. H. F. \& Goldenberg, N. (1947). F. Soc. chem. Ind., Lond., 66, I17.

Lampitt, L. H., Fuller, C. H. F., Goldenberg, N. \& Green, G. H. (1947). F. Soc. chem. Ind., Lond., 66, 68.

Lane, J. H. \&: Eynon, L. (1923). F. Soc. chem. Ind., Lond., 42, 32 T.

Leathes, J. B. \& Raper, H. S. (1925). The Fats, 2nd ed. London: Longmans, Green and Co.

Leeson, H. J., Crawford, R. U., Wcbb, J. F., Swan, F., Davey, J. E., Clarke, L. A. \& McHenry, E. W. (1946). Canad. F. publ. Hlth, 37, 97.

Levy, G. B., Murtaugh, J. J. \& Rosenblatt, M. (1945). Industr. Engng Chem. (Anal. ed.), $17,193$.

Liebermann, L. \& Szekely, S. (1898a). Pflüg. Arch. ges. Physiol. 72, 36o.

Liebermann, L. \& Szekely, S. (1898b). F. chem. Soc. Aii, 655.

McCance, R. A. \& Shipp, H. L. (1933). Spec. Rep. Ser. med. Res. Coun., Lond., no. 187.

McCance, R. A. \& Widdowson, E. M. (1946). Spec. Rep. Ser. med. Res. Coun., Lond., no. 235,2 nd ed.

McCance, R. A., Widdowson, E. M. \& Shackleton, L. R. B. (1938). Spec. Rep. Ser. med. Res. Coun., Lond., no. $2 \mathrm{I} 3$.

McHenry, E. W., Ferguson, H. P. \& Gurland, J. (1945). Canad. F. publ. Hlth, 36, 355.

Maynard, L. A. (1944). F. Nutrit. 28, 433.

Monier-Williams, G. W. (1941). Analyst, 66, 319.

Patterson, J. M. \& McHenry, E. W. (1941). Canad. F. publ. Hlth, 32, 362.

Porter, W. L. \& Willits, C. O. (1944). F. Ass. off. agric. Chem., Wash., 27, 179.

Pringle, W. J. S. (1946). Analyst, 71, 490.

Pyke, M. (1945). Proc. Nutr. Soc. 3, I34.

Radley, J. A. (1943). Starch and its Derivatives, 2nd ed. London: Chapman and Hall.

Riddle, A. R. (1944). F. Coun. sci. industr. Res. Aust. I7 (4), 291.

Riggs, E., Perry, H., Patterson, J. M., Leeson, J., Mosley, W. \& McHenry, E. W. (1943). Canad. Y. publ. Hlth, 34, 193.

Saywell, L. G. \& Cunningham, B. B. (1937). Industr. Engng Chem. (Anal. ed.), 17, 193.

Semmons, E. M. \& McHenry, E. W. (1944). Canad. F. publ. Hlth, 35, 286.

U.S.A. National Research Council (1945). Rep. nat. Res. Coun., Wash., no. 122.

Walker, N. H. (1946). 7. Ass. off. agric. Chem., Wash., 29, 255.

Widdowson, E. M. (1936). F. Hyg., Camb., 36, 269.

Widdowson, E. M. (1947). Spec. Rep. Ser. med. Res. Coun., Lond., no. 257.

Widdowson, E. M. \& McCance, R. A. (1936). F. Hyg., Camb., 36, 293.

Widdowson, E. M. \& McCance, R. A. (1943). Lancet, 244, 230.

Wiehl, D. G. (1942). Milbank mem. Fd Quart. Bull. 20, 4.

Wiehl, D. G. (1944). Milbank mem. Fd Quart. Bull. 22, I.

Youmans, J. B., Patton, E. W. \& Keon, R. (1942). Amer. F. publ. Hlth, 32, 1371.

Young, C. M. \& McHenry, E. W. (1943a). Canad. J. publ. Hlth, 34, 8.

Young, C. M. \& McHenry, E. W. (1943b). Canad. $\mathcal{~}$. publ. Hlth, 34, 367 . 